\title{
A comparative study of the pathergy reaction among Turkish and British patients with Behçet's disease
}

\author{
H. YAZICI, ${ }^{1}$ M. A. CHAMBERLAIN,$^{2} Y$. TÜZUN ${ }^{3}$ S. YURDAKUL,${ }^{1}$ AND A. \\ MÜFTÜO GLU ${ }^{4}$
}

From the ${ }^{1}$ Division of Rheumatology, Department of Medicine, Cerrahpasa Medical Faculty, University of Istanbul, Turkey; the ${ }^{2}$ Department of Rheumatology, the General Infirmary, Leeds, England; the ${ }^{3}$ Department of Dermatology, Cerrahpasa Medical Faculty, University of Istanbul, Turkey; and the ${ }^{4}$ Division of Haematology, Department of Medicine, Cerrahpasa Medical Faculty, University of Istanbul, Turkey

SUMMARY Forty-eight Turkish and 12 British patients along with 24 Turkish and 7 British healthy controls were assessed for the presence of the pathergy phenomenon. A photographic method with 'blind' reading was utilised. The pathergy phenomenon was present only among the Turkish patients.

The hyperreactivity of the skin to a needle prick (the pathergy test) is a curious phenomenon almost unique to Behçet's disease or syndrome (BS). ${ }^{1}$ We have previously demonstrated its sensitivity and specificity, ${ }^{1}$ the inter- and intraobserver variations, ${ }^{2}$ and diagnostic usefulness ${ }^{34}$ in patients with BS from Turkey. In Japan, although formal figures are lacking, the pathergy phenomenon is reported to be present in the majority of the patients. ${ }^{5}$ However, other students of this disease doubted its existence. ${ }^{67} \mathrm{We}$ believe the lack of positivity of this phenomenon among the British and American patients has been the main cause of this scepticism. We therefore compared the prevalence of the pathergy test in 2 groups of patients and in parallel controls from Istanbul, Turkey, and Leeds, England, in a blind study by means of photography.

\section{Patients and methods}

Forty-eight patients from Istanbul and 12 from Leeds were studied. Twenty-four apparently healthy Turkish and 7 British hospital staff served as controls. All Turkish and 11 British patients fulfilled O'Duffy's criteria $^{8}$ for diagnosis. One British patient had aphthae and genital ulceration only. All Turkish and British patients were Caucasians except for one Pakistani in the British group. The pathergy test was done as previously described. ${ }^{1}$ Needles of the same kind $(21 \mathrm{G})$ and manufacturer were used in both countries. 1X1 colour slides of the puncture sites

Accepted for publication 21 January 1983.

Correspondence to Dr H. Yazici. were taken at 48 hours. To obviate differences in background due to light effects observed on some slides black paper was used to cover all parts of the slides except the needle site and its immediate vicinity, before the blind reading. Two observers, unaware of the hypothesis being tested, interpreted the slides on a $0-3+$ scale $(0=$ only a needle mark, $1+=$ papule only, $2+=\mathrm{a}$ 'small' pustule, $3+=\mathrm{a}$ 'large' pustule) in a blind fashion in a single session. For statistical analysis only a $2+$ or $3+$ result was considered typically positive in that pustule formation was present. Either observer interpreted each slide twice. The inter- and intraobserver errors (only positive-negative variability being considered) were calculated as previously described. ${ }^{2}$

\section{Results}

Inter- and intraobserver errors of the method were $22 \%$ and $15.5 \%$ respectively. Observer 1 read all controls as 0 . This was also the case for observer 2 except in 2 instances, where she read a $1+$ for a Turkish and a British control on her second reading. Turkish probands had significantly fewer 0 readings on all 4 occasions, whereas this was not observed among the British (Table 1). Among the British probands 2 had a $1+$ score once and 1 had a $1+$ score twice among the 4 occasions his/her reaction was interpreted. Nine British patients had a $0+$ reading throughout. Among the Turkish probands there were again 9 patients whose readings were all $0+(9 / 48 \mathrm{vs.}$ $\left.9 / 12, \chi^{2}=11.91, p<0 \cdot 001\right)$. The remaining 39 Turkish patients in $156(39 \times 4)$ observations had $0+=$ 
Table 1 Pathergy readings

\begin{tabular}{|c|c|c|c|c|}
\hline & $n^{*}$ & $\begin{array}{l}\text { O score on all } \\
\text { four readings }\end{array}$ & $\begin{array}{l}2+o \\
\text { at lea }\end{array}$ & $\begin{array}{l}3+\text { score in } \\
\text { t one reading }\end{array}$ \\
\hline \multicolumn{5}{|l|}{ Turkish } \\
\hline Probands & 48 & \multirow{2}{*}{\multicolumn{2}{|c|}{${ }_{23}^{9} \chi^{2}=5.73, p<0.02$}} & 28 \\
\hline Controls & 24 & & & \\
\hline British & & & & 0 \\
\hline Probands & 12 & \multirow{2}{*}{\multicolumn{2}{|c|}{$\frac{9}{6} x^{2}=0.92, p>0.05$}} & 0 \\
\hline Controls & 7 & & & 0 \\
\hline
\end{tabular}

*Numbers refer to individuals tested.

$28 ; 1+=72 ; 2+=41 ;$ and $3+$ reading 15 times. If one considered a $2+$ or $3+$ reading at least once in 4 observations as a positive pathergy test, then $28 / 48$ $(58 \%)$ of the Turkish probands would have had a positive pathergy test, while all British patients and controls from either country would have had negative pathergy reactions.

\section{Discussion}

The photographic method of reading the pathergy reaction increases the variability ${ }^{2}$ and decreases the sensitivity ${ }^{13}$ of the test. We believe this is mainly due to lessening of depth appreciation on a slide; thus the interpretation of papules becomes difficult. Nevertheless, it served its purpose of bringing out the differences between the 4 groups of subjects.

The absence of the pathergy phenomenon among the British patients is another major point of difference between the Turkish and British patients with BS, in addition to the already established different HLA association. ${ }^{9}$ We had previously demonstrated that HLA B5 and pathergy positivity did not go together among the Turkish patients. ${ }^{3}$ Thus the absence of a positive pathergy test among the British patients cannot readily be explained by different HLA association.

It is to be noted that there are other regional differences in clinical and laboratory findings in BS. Japanese and Turks both share the high prevalence of HLA B51 but the HLA DR5 association is unique to the Japanese patients. ${ }^{910}$ Moreover involvement of the colon is common among Japanese but rare among Turkish and British patients. ${ }^{511} 12$ These findings justify the use of the term syndrome rather than disease in describing the entity originally described by Behçet. ${ }^{13}$ Furthermore the absence of the pathergy reaction among British patients would suggest that it does not have an important role in the pathogenesis of this entity.

This work was in part supported by the Turkish Scientific Research Council (TUBITAK-TAG 484).

\section{References}

1 Tüzün Y, Yazıcı H, Pazarı H, Yalçın B, Yurdakul S, Müftüoglu A. The usefulness of the nonspecific skin hyperreactivity (the pathergy test) in Behçet's disease in Turkey. Acta Derm Venereol (Stockh) 1979; 59: 77-9.

2 Altaç M, Tüzün Y, Yurdakul S, Binyıldız P, Yazıcı H. The validity of the pathergy test (non-specific skin hyperreactivity) in Behçet's disease: a double blind study by independent observers. Acta Derm Venereol (Stockh) 1982; 62: 158-9.

3 Yazıcı H, Tüzün Y, Pazarlı H, Yalçın B, Yurdakul S, Müftüoglu A. The combined use of HLA-B5 and pathergy test as diagnostic markers of Behçet's disease in Turkey. J Rheumatol 1980; 7: 206-10.

4 Özyazgan Y, Pazarlı H, Yazıcı H, Yurdakul S, Tüzün Y, Altaç M, Ülkü B and Müftüoglu A. Usefulness of HLA determination and pathergy test in the diagnosis of uveitis in Turkey. $\mathrm{Br} J$ Ophthalmol 1981; 65: 798-9.

5 Shimizu T. Clinicopathological studies on Behçet's disease. In: Dilşen N, Koniçe M, Övül C, eds. Behçet's disease. Amsterdam: Excerpa Medica, 1979: 467: 9-43.

6 O'Duffy J D. Summary of international symposium on Behçet's disease. J Rheumatol 1978; 5: 229-33.

7 Lehner T, Barnes CG. Criteria for diagnosis and classification of Behçet's syndrome. In: Lehner T, Barnes CG, eds. Behçet's syndrome London: Academic Press, 1979: 1-7.

8 O'Duffy JD. Suggested criteria for diagnosis of Behçet's disease. Book of abstracts, VI Pan American congress of rheumatic disease. Toronto: 1974: 18.

9 Yazıcı H. Chamberlain M A, Schreuder I, D'Amaro J, Müftüoglu A. HLA antigens in Behçet's disease: a reappraisal by a comparative study of Turkish and British patients. Ann Rheum Dis 1980; 39: 344-8.

10 Ohno S, Ohguchi M, Matsuda H, Wakisaka A, Aizawa M. Close association of HLA-Bw51, MT2 and Behçet's disease. International conference on Behçet's disease, Tokyo, Japan, October 1981.

11 Dilşen N, Koniçe M, Övül C. Clinical evaluation of 106 cases of Behçet's disease. In: Dilşen N, Koniçe M, Övül C, eds. Behçet's disease. Amsterdam: Excerpta Medica, 1979: 467: 124-9.

12 Sladen G E, Lehner T. Gastro-intestinal disorders in Behçet's syndrome and a comparison with recurrent oral ulcers. In: Lehner T, Barnes C G, eds. Behçet's syndrome London: Academic Press, 1979: 151-8.

13 Behçet $H$. Über residivievende aphtose, durchein Virus verursachte Geschwüre am Mund, am Auge and an den Genitalien. Dermatol Monatsschr 1937; 105: 1152-7. 